\title{
Jigsaw and Student Team Achievement Division (STAD) Techniques in Teaching English Reading
}

\author{
Oleh: \\ Caesar Astri Perwitasari, Ag. Bambang Setiyadi, Gede Eka Putrawan \\ Program Studi Pendidikan Bahasa Inggris \\ FKIP Universitas Lampung \\ mpark76@yahoo.com
}

\begin{abstract}
Abstrak. Tujuan penelitian ini adalah untuk menemukan hambatan yang dihadapi oleh siswa selama penerapan teknik Jigsaw dan STAD. Penelitian ini dilakukan melalui desain kualitatif. Populasi dari penelitian ini adalah siswa kelas dua di SMPN 1 Abung Surakarta. Hasil penelitian ini menunjukkan bahwa terdapat hambatan yang dialami oleh siswa yang meliputi: (1) keterbatasan kosa kata; (2) kesulitan pada kemampuan pemahaman bacaan; (3) kelas yang terlalu berisik; (4) beberapa siswa yang tidak memiliki latar belakang pemahaman pada materi yang diberikan; (5) kurangnya rasa percaya diri pada saat mengungkapkan pendapat; (6) proses pembelajaran didominasi oleh siswa yang memiliki kemampuan yang tinggi. Hal ini dapat disimpulkan bahwa terdapat beberapa hambatan yang ditemui selama proses pembelajaran membaca yang menggunakan teknik Jigsaw, dan STAD.
\end{abstract}

Kata Kunci: Teknik Jigsaw, Membaca, Teknik STAD

\begin{abstract}
The objectives of the research were aimed at finding out the responses the students had during the implementation of Jigsaw technique and Student Team Achievement Division (STAD). This research was done through a qualitative design. The population of this research was the second grade students at SMPN 1 Abung Surakarta. The result showed that there were some obstacles found during the implementation of the Jigsaw and STAD Technique as follows: (1) limited vocabulary knowledge; (2) difficulty level of the text (readability); (3) noisy class situation; (4) no students' background knowledge; (5) hesitancy to express opinions; (6) class dominated by the smart students. The results showed that there were obstacles that students faced during teaching, and learning reading comprehension in the class using Jigsaw, and STAD Technique.
\end{abstract}

Keywords: Jigsaw Technique, reading comprehension, STAD Technique 


\section{INTRODUCTION}

English is one of international languages. This language is used all over the world. As a result, Indonesian government decided that English is a foreign language in Indonesia. In addition, it is the first foreign language that is taught as a compulsory subject in junior and senior high schools and university in Indonesia.

There are four skills that should be mastered by the students in learning a language, such as listening, reading, speaking and listening. A teacher should be involved with these skills in the teaching and learning process in the classroom. However, in this research the researcher focused on reading comprehension for the students in the second grade of Junior High School.

Based on the pre-observation in the second grade of SMPN 1 Abung Surakarta, it was found that there were some problems that students faced when they studied English, especially in reading activity such as low motivation, lack of English vocabularies, and difficulties in identifying aspects of reading.

Low motivation might be caused by the teacher who less stimulated them to learn English especially in reading aspects. The teacher tended to make the students become passive audience because he/she just invited them to read their own text and answer the questions. Mostly, the teacher did not lead the students to comprehend some aspects of reading such as main idea, spesific information, reference, inference and vocabulary. Besides, the inappropriate selection of text which would be going to be discussed in the class might not attract the students' attention. Therefore, they had low motivation in learning English, especially in reading activity. They could not achieve the achievement standard on English subject.

On the other hand, the studies (e.g. Ayu, 2013; Andam, 2013; and Kurnia, 2013) stated that SMA students had difficulties in their ability in reading aspects, they had a problem in vocabulary mastery, so they had a difficulty to comprehend the material given by the teacher in the class because without understanding the words in the context they might not comprehend the purpose of the whole text. In addition, the students also had a difficulty in identifying characteristics of a text, differentiating references and inferences, identifying the main idea, etc.

In reading comprehension, the ability of students to comprehend a main idea of a text is important because they might not comprehend the whole content. Unfortunately, not all students can identify the main idea of the text. Most of them must read the whole text in order to know the aim of the text. So that, based on these problems, a teacher has an important role in English reading class. The 
teacher as the manager of the learning process in the class should find a technique which can guide the students to have high ability and motivation in learning English especially in reading aspects.

As we know that there are many kinds of teaching methods in the class. Some of them are Jigsaw and Student Team Achievement Division (STAD). Jigsaw is an appropriate method for Junior High School because this method is an efficient teaching method that encourages listening, engagement, interaction, peer teaching, etc. Jigsaw is a cooperative learning which is designed to improve the responsibility of themselves and the other learners. The students not only learn the material given by the teacher in the class, but they also have to teach those materials to their own group.

Johnson and Johnson (2006) did a research about the cooperative learning of Jigsaw model and the result shows that the cooperative interaction has a wide range of influences of child development. The influences include: (1) increasing the learning outcome; (2) increasing the student's memory; (3) increasing the positive attitude to the teacher; (4) increasing intrinsic motivation; (5) increasing the ability of mutual cooperation; (6) increasing the student's pride; (7) increasing the heterogeneous relationship.

Moreover, Student Team Achievement Division (STAD) is a type of the simplest cooperative learning. It is an approach that emphasizes on the activity and interaction among students to motivate and help each other to master the subject matter in order to achieve the maximum score. When a teacher tries to implement the STAD technique in the teaching process, there are some advantages that would be obtained as follows: (a) it helps the students learn the subject matter being discussed; (b) the cooperative learning makes the students master to debate; (c) students learn about how to respect others' opinions, and notes the benefits thing on behalf of together; (d) the rewards given will boost the student's motivation. The students who have low ability in learning English may help to increase the materials.

Santosh (2012) states that both Jigsaw and STAD proved to be significantly effective in raising the academic achievement of the students than the traditional method because the cooperative learning will divide the students into small groups, in order to help each other to comprehend the materials. From the previous elaboration, the researcher was interested in conducting research on Jigsaw Technique and Student Teams Achievement Division (STAD) in teaching reading of recount text of the second-grade students of SMPN 1 Abung Surakarta, North Lampung in the academic year 2016/2017. Based on the result of preobservation in SMPN 1 Abung Surakarta, problems related to the learning of 
reading skill are apparent, for example, more than $80 \%$ of the students scores are below 70 as the standard minimum for reading tasks and they seem bored with learning of reading. Then, the researcher concluded that there was a problem that needed to be answered, namely the obstacles faced during the implementation of Jigsaw and STAD.

\section{METHOD}

This research was done through a qualitative design. The subjects of this research were 26. The qualitative data were collected by using interview, observation, and triangulation design. The subjects of this research were students of Class VIII B and that of VIII C of SMPN 1 Abung Surakarta in the second semester of 2016/2017 academic year. These data were collected through interview and observation techniques. To get more valid data, the researcher had interviewed some students and the teacher. The interview was conducted after the researcher gave treatments to the students. It was applied to identify the students' problems during teaching and learning process. The researcher had asked some students who seemed to get problem in the process. The researcher asked the students about their feeling and problem when taught through the Jigsaw and STAD Technique.

\section{RESULTS}

In order to get the data of students' responses about the implementation of Jigsaw and STAD technique, the interview was delivered. The result of students' responses about the implementation of Jigsaw and STAD technique can be seen in the table below:

Table 1. Result of Students' Interview

\begin{tabular}{|c|c|c|c|}
\hline No. & Pertanyaan & Yes & No \\
\hline 1. & $\begin{array}{l}\text { Apakah Anda sering belajar secara berkelompok di } \\
\text { kelas? }\end{array}$ & $44 \%$ & $56 \%$ \\
\hline \multirow{2}{*}{2.} & $\begin{array}{l}\text { Apakah Anda mudah memahami instruksi yang } \\
\text { diberikan oleh peneliti selama proses pembelajaran } \\
\text { bahasa Inggris menggunakan teknik Jigsaw? }\end{array}$ & $68 \%$ & $32 \%$ \\
\hline & $\begin{array}{l}\text { Apakah Anda mudah memahami instruksi yang } \\
\text { diberikan oleh peneliti selama proses pembelajaran } \\
\text { bahasa Inggris menggunakan teknik STAD? }\end{array}$ & $52 \%$ & $48 \%$ \\
\hline \multirow[b]{2}{*}{3.} & $\begin{array}{l}\text { Apakah Anda mudah memahami materi bahasa Inggris } \\
\text { yang diberikan menggunakan teknik Jigsaw? }\end{array}$ & $60 \%$ & $40 \%$ \\
\hline & $\begin{array}{l}\text { Apakah Anda mudah memahami materi bahasa Inggris } \\
\text { yang diberikan menggunakan teknik STAD? }\end{array}$ & $50 \%$ & $50 \%$ \\
\hline \multirow[t]{2}{*}{4.} & $\begin{array}{l}\text { Apakah Anda percaya diri dalam mengungkapkan } \\
\text { pendapat anda selama proses pembelajaran bahasa } \\
\text { Inggris menggunakan teknik Jigsaw? }\end{array}$ & $68 \%$ & $32 \%$ \\
\hline & Apakah Anda percaya diri dalam mengungkapkan & $40 \%$ & $60 \%$ \\
\hline
\end{tabular}




\begin{tabular}{|c|c|c|c|}
\hline & $\begin{array}{l}\text { pendapat anda selama proses pembelajaran bahasa } \\
\text { Inggris menggunakan teknik STAD? }\end{array}$ & & \\
\hline \multirow{2}{*}{5.} & $\begin{array}{l}\text { Apakah pembelajaran bahasa Inggris menggunakan } \\
\text { teknik Jigsaw menyenangkan? }\end{array}$ & $96 \%$ & $4 \%$ \\
\hline & $\begin{array}{l}\text { Apakah pembelajaran bahasa Inggris menggunakan } \\
\text { teknik STAD menyenangkan? }\end{array}$ & $60 \%$ & $40 \%$ \\
\hline \multirow{2}{*}{6.} & $\begin{array}{l}\text { Apakah penerapan teknik Jigsaw dapat meningkatkan } \\
\text { motivasi belajar? }\end{array}$ & $100 \%$ & - \\
\hline & $\begin{array}{l}\text { Apakah penerapan teknik STAD dapat meningkatkan } \\
\text { motivasi belajar? }\end{array}$ & $65 \%$ & $35 \%$ \\
\hline \multirow[b]{2}{*}{7.} & $\begin{array}{l}\text { Apakah pembelajaran bahasa Inggris yang } \\
\text { menggunakan teknik Jigsaw mudah dipahami/ diikuti? }\end{array}$ & $100 \%$ & - \\
\hline & $\begin{array}{l}\text { Apakah pembelajaran bahasa Inggris yang } \\
\text { menggunakan teknik STAD mudah dipahami/ diikuti? }\end{array}$ & $55 \%$ & $45 \%$ \\
\hline
\end{tabular}

The question number one shows that $56 \%$ students said that they were seldom working in group discussion during the teaching and learning of English in the class. Their teacher taught them through traditional method in which they were just invited by the teacher to pay attention to the teacher's explanation and did the task given by the teacher. They stated that by using traditional method, the technique used in the class was monotonous. They argued that they felt bored with the technique and did not understand the materials that they learned in the class. She used traditional method in teaching and learning process in the class. She did not apply a cooperative learning (for example Jigsaw and STAD techniques) in teaching English in the class.

The questions number two and three were the questions about the student's vocabulary. The question number two showed that $68 \%$ in Jigsaw Class, and 52\% in STAD Class could not comprehend the instruction given by the teacher and the question number three showed that $60 \%$ in Jigsaw Class, and $50 \%$ in STAD Class could not comprehend the materials given by the teacher. Based on the data above it could be inferred that most of the students did not comprehend the instruction and materials given by the teacher in teaching reading because limited vocabulary. Most of them said that English vocabulary is too much and they did not memorize it well. For example: the word "make" can be interpreted as "membuat", but it could also be mean "menyebabkan".

The question number four showed that $68 \%$ of the students in Jigsaw Class, and $40 \%$ of the students in STAD Class felt hesitancy to express their opinion in learning English. Most of them afraid of derison. Those feeling made the students' spirit weaked. They did not dare to ask questions or express their opinion. So what they wanted to ask can not be uttered.Regarding the result of those interview, the students responded negatively because most of students tend to scary in making something wrong in express their opinion. 
According to those table, most of students responded positively to this technique because most of them feel enjoyed to follow the teaching and learning process in the class, most of them the students feel motivated to improve their reading ability. The data shows that (100\% in Jigsaw Class and $65 \%$ in STAD Class) responded agree that the Jigsaw Technique increased their motivation to learn English especially in reading aspect. Moreover, (100\% in Jigsaw Class and 55\% in STAD Class) said that those techniques are easier to undertand so that the ability of the students was increased. Regarding the result of the interview, the students responded positively. They argued that the classroom interaction was high and also they can ask to the other students so, they felt enjoy in the teaching learning process. Based on the result of the research in the second grade of Junior High School at SMPN 1 Abung Surakarta, there were some obstacles found during the implementing the Jigsaw and STAD Technique as follows: (1) limited vocabulary knowledge, (2) difficulty level of the text, (3) the class was noisy, (4) some of the students had no background knowledge about the materials in the class, (5) they had hesitancy to express their opinions, (6) teaching and learning process was dominated by the smart students and some of the students cannot be independent.

\section{DISCUSSIONS}

Referring to the result of interview and observation at second grade of SMPN 1 Abung Surakarta, there were problems related to the two techniques in teaching English reading comprehension. Besides, in each question, the students were asked to mention and gave their reason as a perspective point to the teacher. This section was conducted in $2 \times 45$ minutes. The result of this test analyzed manually and used to answer the second research question in chapter one, such as "what are the obstacles in conducting teaching reading using the Jigsaw and STAD technique in second grade of Junior High School at SMPN 1 Abung Surakarta?"

Based on the result of the research in second grade of Junior High School at SMPN 1 Abung Surakarta, it can be concluded that there were some obstacles found during the implementing the Jigsaw and STAD Technique as follows: (1) limited vocabulary knowledge. Vocabulary knowledge is an essential part of English. According to Lewis and Hill (1997: 120), vocabulary is very important for the students. It is more than grammar for communication purpose, particularly in the early stage when the students are motivated to learn the basic words. Without having proportional English vocabulary, students would get difficulty in using English. The students who had difficulty in understanding of reading, had a serious problem between his or her knowledge of words meanings and the words used in the text. For example, when the teacher asked the students about the word "crowd" the students did not know about the meaning of it. Most of them thought that it was similar with the word "road". Besides, most of them did not have a 
dictionary while learning English. Most of them embarrassed to ask a difficult word to the teacher, (2) difficulty level of the text (readability). According to Sakri (1993: 95), readability depends on the vocabulary. The texts that contain many unusual words are more difficult to understand than those that used in everyday. It means that the texts that were too difficult would made the students tend to difficult to comprehend the materials so they would made many errors. On the other hand, the texts that were too easy would not guarantee the student's achievement, (3) the class was noisy. According to the result of the observation in SMPN 1 Abung Surakarta, the condition of the class was noisy when the students tend to be active with the materials or methods given by researcher in the class. This statement in line with Shore (2003), A child might tap her fingers or roll her pencil without knowing she is doing it. To anticipate this, the researcher tried to move toward to the students. If they were made noisy while the researcher teaching, the researcher walked in her/his direction while continuing to talk to the class. Stand near the students for a minute or two, perhaps making eye contact with her/his. Our presence might be enough to get her/his to stop. Moreover, if a student is making noise to get attention, look for occasions to pay attention to her while she's/he's exhibiting positive behavior or enjoying an academic success. A student who's recognized for positive behavior would feel less driven to seek attention in inappropriate ways, (4) some of the students had no background knowledge about the materials in the class. It was much easier to read with understanding if the reader already processes some prior knowledge of the topic. The using of the school textbook as the medium for first introducing new information to students was not usually the most effective method of delivery. This statement in line with Michael (2007: 39), we need to spend more time to finding out what our students know and don't know, and can do or not do, when they enter our classroom. It is better to provide information first by using video, posters, mini-lecture, and discussion to build background knowledge before the students are expected to read about the theme in printed text. This is particularly important for weaker students, (5) they had hesitancy to express their opinions. Based on the result of the research in second grade of Junior High School at SMPN 1 Abung Surakarta, there were some factors that the students had hesitancy to expressed their opinions as follows: (a) the students felt unconfident with their ability in comprehending the materials. In this problem, the researcher as the facilitator in the class tried to motivate them in order to confident with themselves when they have to express their own opinion to the others. For improving students' motivation to study English, the teacher or lecturer should apply the appropriate technique. That technique should help the students to encourage the students to enjoy the learning. So that, in this research, the researcher used Jigsaw, and STAD Technique in order to motivate the students, (b) the students tend to scary in making something wrong in express their opinion. The students tend to be shy if their answer is incorrect. Similar with the problem above, the researcher 
tried to motivate the students when they have to express their opinion. Motivation is very important for the students because they can increase their ability if they can share the ideas with the others, so the students can enjoy the teaching and learning in the class. This statement is in line with Quin (2006) most students enjoyed working with a partner and this gave them motivation to do their work. Motivation is a key component in learning. If the students fell enjoy, then the learning atmosphere is positive and it can make the students more motivated, so, it can promote the students achievement in all skill, (6) teaching and learning learning process in the class was dominated with the smart students and some students cannot be independent. For this problem, the researcher tried to remember the students that they cannot dominate the class and should be independent student because in Jigsaw and STAD technique asked them to working in group and help each other. So, they were could solved the problems together. This statement in line with Jia (2013), classroom interaction is vital to improve the effect of language classroom teaching and learning. In building the interaction, the researcher paid attention to all the students in the classroom. So, the interaction between the researcher and students was good. Interaction is really important in order to make the students enjoy in the process of learning. When the classroom interaction is good, the students would be motivated in joining the lessons.

\section{CONCLUSION}

After conducting the research at the second grade of SMPN 1 Abung Surakarta, there was a conclusion as follows: there were some problems faced by the students during the implementation of Jigsaw and STAD as follows: (a) it was difficult for the students to express their opinions; (b) most of students had no background knowledge of the material discussed in the class; (c) most of students needed more time to comprehend the materials; (d) the class was noisy because the researcher could not handle it well when the students were too active during the learning process; (e) the students had difficulty to comprehend the whole text because of their limited vocabularies.

\section{SUGGESTIONS}

Based on the results of the research and conclusion, the suggestions were made as follows: (1) English teacher who wants to use Jigsaw and STAD methods should develop an interesting situation in order to trigger the students to participate and practice in the classroom; (2) For other researchers who want to conduct the research with the similar method should prepare the materials of Jigsaw and STAD well, should ask many sources related to the learning effectiveness, and should prepare the data collecting technique to get complete result; (3) schools 
have to facilitate the teaching and learning process in order to increase the student's achievement.

\section{REFERENCES}

Andam, D.R. 2013. The effect of using pre-questioning on student's reading comprehension at second grade of SMPN 1 Seputih Banyak. Bandar Lampung: Lampung University

Ayu, D.M. 2013. The implementation of Jigsaw technique in improving the student's oral production of recount text. Bandar Lampung: Lampung University

Jia, X. 2013. The Application of Classroom Interaction in English Lesson. ICETIS Journal, pp. 209-212

Johnson, D. W., \& Johnson, F. 2006. Joining together: group theory and group skills. ( $7^{\text {th }}$ ed.). Boston: Allyn \& Bacon

Kurnia, N.D. 2013. A comparative study of the student's reading achievement between those who are taught through predictive and through making inferences at the second grade of SMAN 1 Kota Gajah, Lampung: The Faculty of Teacher Training and Education University of Lampung

Lewis, Michael and Hill, Jamie. 1997. Practical Techniques for Language Teaching. London: Commercial Colour Press, Plc

Michael, J. 2007. Conceptual Assessement in the Biological Science: a National Science Foundation-Sponsored workshop. Adv Physiol Educ 31: 10-16

Sakri, A. 1993. Bangun Kalimat Bahasa Indonesia. Bandung: ITB Bandung

Santosh. 2012. A comparative study of the effectiveness of Student Teams Achievement Division (STAD) and Jigsaw methods of cooperative learning. Unpublished thesis for Doctor of Phylosophy in Education, Maharshi Dayanan University, Rohtak

Shore, K. 2003. A Practical A-Z Guide for Managing Classroom Behavior Problems. USA: Jossey Bass

Quinn, P. 2006. Cooperative learning and student motivation. Education and Human Development Master's Theses 